We wish to thank Miss Linda Glaze for technical help and Miss Vivian Barlow for secretarial services. Dr. C. D. Granger, of Lepetit Pharmaceuticals, kindly arranged a generous supply of rifamide (Rifocin-M).

\section{References}

Ayliffe, G. A. J., and Davies, A. (1965). British fournal of Pharmacology and Chemotherapy, 24, 189.
Citron, K. M., and May, J. R. (1969). Tubercle, 50, 329.

Fürész, S., Arioli, V., and Scotti, R. (1965). Arzneimittel-Forschung, 15, 802 Larmi, T. K., Fock, G., and Vuopio, P. (1958). Acta Chirurgica Scandinavica, 114, 379

Maingot, R. (1963). Annals of the Royal College of Surgeons of England, 32, 42. Mason, G. R. (1968). Archives of Surgery, 97, 533.

Payne, R. A. (1969). British Fournal of Surgery, 56, 200.

Robertson, H. R. (1958). Annals of the Royal College of Surgeons of England,

23, 141. C., Bogart, J. N., and Heggers, J. P. (1970). Surgery, 68, 471.

Stratford, B. C., and Dixson, S. (1966). Medical fournal of Australia, 1, 1.

Watson, J. F. (1969). Military Medicine, 134, 416.

\title{
Controlled Comparison of the Efficacy of Fourteen Preparations in the Relief of Postoperative Pain
}

\author{
J. D. MORRISON, W. B. LOAN, J. W. DUNDEE
}

British Medical fournal, 1971, 3, 287-290

\section{Summary}

Thirteen analgesic drugs, four of them at two dose levels, four analgesics in combination with antagonist or neuroleptic agents, and saline have been evaluated simultaneously in the relief of postoperative pain. The method of assessment was designed to favour drugs which provided freedom from pain with minimum depression of consciousness. Only levorphanol $2 \mathrm{mg}$ proved significantly superior to pethidine $100 \mathrm{mg}$, which was used as the standard reference drug. Oxycodone $10 \mathrm{mg}$, pentazocine $20 \mathrm{mg}$, and the morphine $10 \mathrm{mg}$ and cyclizine $50 \mathrm{mg}$ combination were the most successful of the remaining drugs. None of the drug combinations was significantly better than the analgesic drug given alone.

\section{Introduction}

There are several possible approaches to the symptomatic relief of severe pain-namely, interruption of afferent nerve pathways, either chemically or surgically; "dissociation" of the patient from his pain, which may be achieved by such psychological devices as suggestion or hypnosis, or pharmacologically by agents such as chlorpromazine ; and use of centrally acting analgesics, which may also produce mild sedation and dissociate patients from their pain. Only the latter, which involves the systemic use of drugs with opiate-like actions, offers ease of administration compatible with everyday clinical practice. It is therefore of importance that the relative merits of the numerous available drugs of this class should be established. Though the literature relating to these substances is abundant reports have usually encompassed only a few agents, and lack of standardized methodology makes the compiling of an overall assessment difficult.

The study reported here, which occupied four years, was undertaken to answer this need.

Department of Anaesthetics, the Queen's University of Belfast, and Royal Victoria Hospital, Belfast, Northern Ireland

I. D. MORRISON, M.D., F.P.A. R.C.S., Senior Registrar

J. W. DUNDEE, M.D., F.F.A. R.C.S., Professor of Anaesthetics

Belfast City Hospital

W. B. LOAN, M.D., P.F.A. R.C.S.I., Consultant Anaesthetist

\section{Method and Material}

The method has been previously described and presented with a critical assessment of its sensitivity and validity (Loan et al., 1968). Patients who had undergone upper or lower abdominal surgery were admitted to the trial when the nursing staff considered that they required their first postoperative analgesic. Pain severity was assessed before and after treatment on four criteria-namely, patient's and observer's subjective estimates on a five-point scale and, with upper abdominal wounds, measurements of vital capacity and peak expiratory flow rate. Pain relief was inferred from changes in these criteria and also estimated by the patient's direct retrospective comparison with his pretreatment state. Treatment in any individual patient was classified as a success only when all these criteria showed improvement, and this "overall" assessment was used in the final comparison of drugs.

The study was carried out in the same environment by two observers who were successive full-time research workers. Drugs were administered and assessments made under doubleblind conditions.

The preparations, doses, and numbers of patients given each drug are listed in Table $I$, and mean ages and weights of patients are shown in Table II. Ideally, each drug should be included at several dose levels so that the basis of comparison would be dose/response curves, thus eliminating differences due solely to dosage. In practice such an approach would have required a vastly greater number of subjects and would have extended the time far beyond the four years taken to complete this study, which was mainly concerned with com-

TABle I-Details of Drugs and Dosages used.

\begin{tabular}{|c|c|c|c|c|c|c|c|c|c|}
\hline & & & & & & & & $\begin{array}{l}\text { Dose } \\
\text { (mg) }\end{array}$ & $\begin{array}{l}\text { No. of } \\
\text { Patients }\end{array}$ \\
\hline Morphine & .. & . & .. & . & .. & $\cdots$ & .. & \multirow{14}{*}{$\begin{array}{c}10 \\
15 \\
5 \\
20 \\
10 \\
50 \\
2 \\
2 \\
20 \\
40 \\
10 \\
5 \\
100 \\
1 \\
2 \\
0.1 \\
0.2 \\
100 / 1 \cdot 25 \\
10 / 50 \\
0.2 / 5 \\
2 / 5\end{array}$} & \multirow{14}{*}{$\begin{array}{l}80 \\
20 \\
20 \\
20 \\
20 \\
40 \\
40 \\
20 \\
20 \\
40 \\
20 \\
20 \\
40 \\
20 \\
40 \\
20 \\
40 \\
20 \\
20 \\
40 \\
40\end{array}$} \\
\hline $\begin{array}{l}\text { Diamorphine } \\
\text { Papaveretum }\end{array}$ & . & .. & . & . & .. & . & .. & & \\
\hline $\begin{array}{l}\text { Papaveretum } \\
\text { Oxycodone }\end{array}$ & $\because$ & . & $\cdots$ & $\because$ & . & $\because$ & $\because$ & & \\
\hline Dihydrocodeine & & $\because$ & $\because$ & $\therefore$ & .. & $\therefore$ & $\ldots$ & & \\
\hline Levorphanol & . & .. & .. & . & . & . & $\cdots$ & & \\
\hline Phenazocine & . & . & $\cdots$ & $\cdots$ & $\cdots$ & $\cdots$ & $\cdots$ & & \\
\hline Pentazocine & . & . & . & . & .. & .. & . & & \\
\hline Methadone & $\therefore$ & . & . & . & .. & . & .. & & \\
\hline $\begin{array}{l}\text { Dextromoramide } \\
\text { Pethidine }\end{array}$ & & $\because$ & $\because$ & $\therefore$ & .. & $\because$ & $\because$ & & \\
\hline Phenoperidine & .. & . & .. & .. & .. & $\ldots$ & .. & & \\
\hline Fentanyl .. & $\ldots$ & $\ldots$ & $\ldots$ & $\ldots$ & .. & $\ldots$ & .. & & \\
\hline Pethidine/levallo & orphan & $\ldots$ & .. & .. & .. & .. & .. & & \\
\hline & zine & & . & . & . & . & .. & & \\
\hline & $\begin{array}{l}\text { ridol } \\
\text { droperid }\end{array}$ & & $\because$. & $\because$ & $\because$ & $\because$ & $\because$ & & \\
\hline Fenoperiome & & & & & & & & & \\
\hline
\end{tabular}


TABLE II-Numbers of Patients in Treatment Groups with Operation Sites, Mean Ages, and Weights

\begin{tabular}{|c|c|c|c|c|c|c|}
\hline \multirow{2}{*}{ Treatment } & & \multicolumn{3}{|c|}{ No. of Patients } & \multirow{2}{*}{$\begin{array}{l}\text { Mean } \\
\text { Weight } \\
\pm \text { S.E. } \\
\text { (kg) }\end{array}$} & \multirow{2}{*}{$\begin{array}{c}\text { Mean } \\
\text { Age } \\
\pm \text { S.E. } \\
\text { (years) }\end{array}$} \\
\hline & & $\begin{array}{c}\text { Upper } \\
\text { Abdominal }\end{array}$ & $\begin{array}{c}\text { Lower } \\
\text { Abdominal }\end{array}$ & Total & & \\
\hline $\begin{array}{l}\text { orphine } 10 \mathrm{mg} \\
\text { orphine } 15 \mathrm{mg} \\
\text { ophorphine } 5 \mathrm{mg}\end{array}$ & 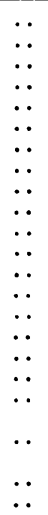 & $\begin{array}{l}40 \\
10 \\
20 \\
10 \\
10 \\
10 \\
20 \\
10 \\
10 \\
20 \\
20 \\
10 \\
20 \\
10 \\
20 \\
10 \\
20 \\
10 \\
10\end{array}$ & $\begin{array}{l}40 \\
10 \\
20 \\
10 \\
10 \\
10 \\
20 \\
10 \\
10 \\
20 \\
20 \\
10 \\
20 \\
10 \\
20 \\
10 \\
20 \\
10 \\
10\end{array}$ & $\begin{array}{l}80 \\
20 \\
40 \\
20 \\
20 \\
20 \\
40 \\
20 \\
20 \\
40 \\
40 \\
20 \\
40 \\
20 \\
40 \\
20 \\
40 \\
20 \\
20\end{array}$ & $\begin{array}{l}64 \pm 2 \cdot 8 \\
63 \pm 3 \cdot 6 \\
65 \pm 3 \cdot 4 \\
62 \pm 3 \cdot 7 \\
64 \pm 4 \cdot 4 \\
64 \pm 2 \cdot 3 \\
62 \pm 2 \cdot 6 \\
62 \pm 2.9 \\
65 \pm 1 \cdot 8 \\
64 \pm 2 \cdot 7 \\
62 \pm 2 \cdot 4 \\
62 \pm 2 \cdot 4 \\
63 \pm 1 \cdot 6 \\
64 \pm 4 \cdot 2 \\
65 \pm 3 \cdot 8 \\
66 \pm 4.1 \\
66 \pm 3 \cdot 8 \\
69 \pm 4 \cdot 7 \\
67 \pm 2 \cdot 3\end{array}$ & 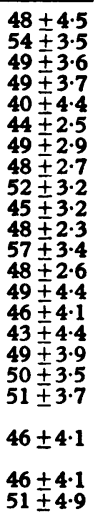 \\
\hline
\end{tabular}

TABLE IV-Rank Order of Efficacy of Analgesia expressed as Percentage of Patients obtaining "Successful" Relief as defined in the Text

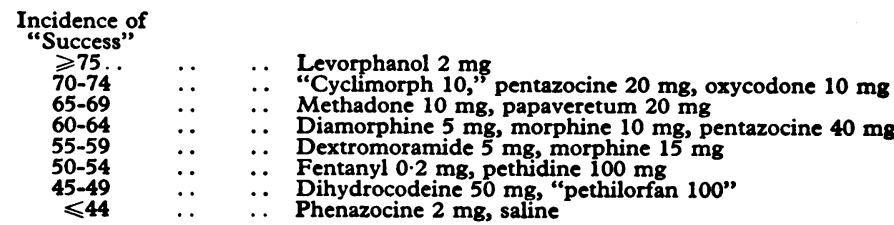

TABLE V-Rank Order of Drugs in respect of Analgesic Potency as judged by Patient's Estimate alone

Groups in Alphabetical Order

Over $80 \%$ pain relief .. Diamorphine $5 \mathrm{mg}$, papaveretum $20 \mathrm{mg}$, oxycodone $10 \mathrm{mg}$, levorphanol $2 \mathrm{mg}$, pethidine $100 \mathrm{mg}$,

75-80\% pain relief . Morphine $10 \mathrm{mg}$, morphine $15 \mathrm{mg}$, pentazocine $20 \mathrm{mg}$, 70-74\% pain relief .. Dextromoramide $2 \mathrm{mg}$, "Pethilorfan 100 " $\begin{array}{lll}50-69 \% \text { pain relief } & 0 & \text { Dihydrocodeine } 50 \mathrm{mg} \text {, fentanyl } 0.2 \mathrm{mg} \text {, phenazocine } 2 \mathrm{mg} \\ \text { Less than } 50 \% \text { pain relief Saline }\end{array}$

TABLE III-Numbers of Patients showing Improvement in the Recorded Criteria after Administration of the Analgesic

\begin{tabular}{|c|c|c|c|c|c|c|c|c|c|c|c|c|c|c|c|c|c|c|c|c|}
\hline \multirow{2}{*}{\multicolumn{3}{|c|}{ Treatment }} & \multicolumn{7}{|c|}{ Upper Abdominal } & \multicolumn{5}{|c|}{ Lower Abdominal* } & \multicolumn{5}{|c|}{ Total } & \multirow{2}{*}{$\begin{array}{c}\text { Total } \\
\text { Overall } \\
\text { Success } \\
(\%) \\
\end{array}$} \\
\hline & & & $\begin{array}{l}\text { No. in } \\
\text { Group }\end{array}$ & O.E. & P.E. & P.R.E. & v.c. & PEFR & Overall & $\begin{array}{l}\text { No. in } \\
\text { Group }\end{array}$ & O.E. & P.E. & P.R.E. & Overall & $\begin{array}{l}\text { No. in } \\
\text { Group }\end{array}$ & O.E. & P.E. & P.R.E. & Overall & \\
\hline $\begin{array}{l}\text { Morphine } 10 \mathrm{mg} \\
\text { Morphine } 15 \mathrm{mg} \\
\text { Diamorphine } 5 \mathrm{mg}\end{array}$ & $\begin{array}{l}\cdots \\
\cdots\end{array}$ & $\begin{array}{l}\cdots \\
\cdots\end{array}$ & $\begin{array}{l}40 \\
10 \\
20\end{array}$ & $\begin{array}{r}30 \\
9 \\
19\end{array}$ & $\begin{array}{r}25 \\
8 \\
17\end{array}$ & $\begin{array}{r}32 \\
8 \\
16\end{array}$ & $\begin{array}{r}28 \\
5 \\
14\end{array}$ & $\begin{array}{l}30 \\
10 \\
14\end{array}$ & $\begin{array}{r}17 \\
3 \\
11\end{array}$ & $\begin{array}{l}40 \\
10 \\
20\end{array}$ & $\begin{array}{r}36 \\
9 \\
19\end{array}$ & $\begin{array}{r}34 \\
8 \\
17\end{array}$ & $\begin{array}{r}34 \\
9 \\
16\end{array}$ & $\begin{array}{r}33 \\
8 \\
13\end{array}$ & $\begin{array}{l}80 \\
20 \\
40\end{array}$ & $\begin{array}{l}66 \\
18 \\
38\end{array}$ & $\begin{array}{l}59 \\
16 \\
34\end{array}$ & $\begin{array}{l}66 \\
17 \\
32\end{array}$ & $\begin{array}{l}50 \\
11 \\
24\end{array}$ & $\begin{array}{l}62 \cdot 5 \\
55 \\
60\end{array}$ \\
\hline $\begin{array}{l}\text { Papaveretum } 20 \mathrm{mg} \\
\text { Oxycodone } 10 \mathrm{mg} \\
\text { Dihydrocodeine } 50 \mathrm{mg} \\
\text { Levorphanol } 2 \mathrm{mg} \\
\text { Phenazocine } 2 \mathrm{mg} . . \\
\text { Pentazocine } 20 \mathrm{mg} \\
\text { Pentazocine } 40 \mathrm{mg} \\
\text { Methadone } 10 \mathrm{mg}\end{array}$ & $\begin{array}{l}\ldots \\
\cdots \\
\cdots \\
\cdots \\
\cdots \\
\cdots\end{array}$ & $\begin{array}{l}\ldots \\
\cdots \\
\cdots \\
\cdots \\
\cdots \\
\cdots\end{array}$ & $\begin{array}{l}10 \\
10 \\
10 \\
20 \\
10 \\
10 \\
20 \\
20\end{array}$ & $\begin{array}{r}9 \\
9 \\
6 \\
19 \\
7 \\
9 \\
17 \\
17\end{array}$ & $\begin{array}{r}8 \\
9 \\
6 \\
18 \\
5 \\
7 \\
14 \\
18\end{array}$ & $\begin{array}{r}8 \\
8 \\
5 \\
15 \\
4 \\
6 \\
8 \\
17\end{array}$ & $\begin{array}{r}8 \\
7 \\
6 \\
19 \\
5 \\
9 \\
15 \\
16\end{array}$ & $\begin{array}{r}7 \\
9 \\
8 \\
8 \\
6 \\
9 \\
16 \\
16\end{array}$ & $\begin{array}{r}4 \\
6 \\
5 \\
15 \\
1 \\
5 \\
11 \\
10\end{array}$ & $\begin{array}{l}10 \\
10 \\
10 \\
20 \\
10 \\
10 \\
20 \\
20\end{array}$ & $\begin{array}{r}8 \\
10 \\
7 \\
17 \\
9 \\
10 \\
18 \\
20\end{array}$ & $\begin{array}{r}9 \\
8 \\
5 \\
15 \\
8 \\
8 \\
15 \\
16\end{array}$ & $\begin{array}{r}10 \\
10 \\
5 \\
17 \\
6 \\
8 \\
17 \\
17\end{array}$ & $\begin{array}{r}9 \\
8 \\
4 \\
15 \\
7 \\
9 \\
14 \\
16\end{array}$ & $\begin{array}{l}20 \\
20 \\
20 \\
40 \\
20 \\
20 \\
40 \\
40\end{array}$ & $\begin{array}{l}17 \\
19 \\
13 \\
36 \\
16 \\
19 \\
35 \\
37\end{array}$ & $\begin{array}{l}17 \\
17 \\
11 \\
33 \\
13 \\
15 \\
29 \\
34\end{array}$ & $\begin{array}{l}18 \\
18 \\
10 \\
32 \\
10 \\
14 \\
25 \\
34\end{array}$ & $\begin{array}{r}13 \\
14 \\
9 \\
30 \\
8 \\
14 \\
25 \\
26\end{array}$ & $\begin{array}{l}65 \\
70 \\
45 \\
75 \\
40 \\
70 \\
62 \cdot 5 \\
65\end{array}$ \\
\hline 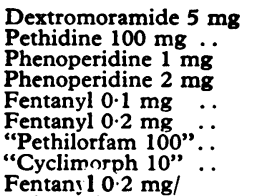 & $\begin{array}{l}\cdots \\
\because \\
\because \\
\therefore \\
\cdots \\
\cdots\end{array}$ & $\begin{array}{l}. \\
\because \\
\because \\
\therefore \\
\therefore \\
\therefore\end{array}$ & $\begin{array}{l}10 \\
20 \\
10 \\
20 \\
10 \\
20 \\
10 \\
10\end{array}$ & $\begin{array}{r}7 \\
19 \\
7 \\
15 \\
7 \\
15 \\
9 \\
9\end{array}$ & $\begin{array}{r}8 \\
18 \\
6 \\
13 \\
5 \\
12 \\
9 \\
8\end{array}$ & $\begin{array}{r}8 \\
15 \\
5 \\
15 \\
5 \\
13 \\
8 \\
9\end{array}$ & $\begin{array}{r}9 \\
7 \\
5 \\
13 \\
7 \\
12 \\
6 \\
7\end{array}$ & $\begin{array}{r}9 \\
9 \\
8 \\
14 \\
6 \\
13 \\
5 \\
7\end{array}$ & $\begin{array}{l}5 \\
6 \\
4 \\
9 \\
4 \\
6 \\
3 \\
5\end{array}$ & $\begin{array}{l}10 \\
20 \\
10 \\
20 \\
10 \\
20 \\
10 \\
10\end{array}$ & $\begin{array}{r}9 \\
18 \\
5 \\
19 \\
6 \\
18 \\
10 \\
10\end{array}$ & $\begin{array}{r}6 \\
15 \\
4 \\
18 \\
5 \\
14 \\
7 \\
9\end{array}$ & $\begin{array}{r}7 \\
13 \\
6 \\
17 \\
6 \\
15 \\
9 \\
9\end{array}$ & $\begin{array}{r}6 \\
15 \\
4 \\
17 \\
4 \\
14 \\
6 \\
9\end{array}$ & $\begin{array}{l}20 \\
40 \\
20 \\
40 \\
20 \\
40 \\
20 \\
20\end{array}$ & $\begin{array}{l}16 \\
37 \\
12 \\
34 \\
13 \\
33 \\
19 \\
19\end{array}$ & $\begin{array}{l}14 \\
33 \\
10 \\
31 \\
10 \\
26 \\
16 \\
17\end{array}$ & $\begin{array}{l}13 \\
28 \\
11 \\
32 \\
11 \\
28 \\
17 \\
18\end{array}$ & $\begin{array}{r}11 \\
21 \\
8 \\
26 \\
8 \\
20 \\
9 \\
14\end{array}$ & $\begin{array}{l}55 \\
52 \cdot 5 \\
40 \\
65 \\
40 \\
50 \\
45 \\
70\end{array}$ \\
\hline $\begin{array}{l}\text { droperidol } 5 \mathrm{mg} . \\
\text { Phenoperidine } 2 \mathrm{mg} \text { | }\end{array}$ & $\cdots$ & . & 20 & 18 & 12 & 18 & 15 & 14 & 9 & 20 & 16 & 16 & 12 & 12 & 40 & 34 & 28 & 30 & 21 & 52.5 \\
\hline $\begin{array}{lll}\text { droperidol } 5 & \mathrm{mg} . . \\
\text { Saline } & . . & \ldots\end{array}$ & $\because$ & $\because$ & $\begin{array}{l}20 \\
40\end{array}$ & $\begin{array}{l}18 \\
18\end{array}$ & $\begin{array}{r}16 \\
9\end{array}$ & $\begin{array}{l}16 \\
11\end{array}$ & $\begin{array}{l}13 \\
21\end{array}$ & $\begin{array}{l}17 \\
31\end{array}$ & $\begin{array}{r}10 \\
5\end{array}$ & $\begin{array}{l}20 \\
40\end{array}$ & $\begin{array}{l}19 \\
23\end{array}$ & $\begin{array}{l}18 \\
18\end{array}$ & $\begin{array}{l}18 \\
21\end{array}$ & $\begin{array}{r}16 \\
9\end{array}$ & $\begin{array}{l}40 \\
80\end{array}$ & $\begin{array}{l}37 \\
41\end{array}$ & $\begin{array}{l}34 \\
27\end{array}$ & $\begin{array}{l}34 \\
32\end{array}$ & $\begin{array}{l}26 \\
14\end{array}$ & $\begin{array}{l}65 \\
17 \cdot 5\end{array}$ \\
\hline
\end{tabular}

*Vital capacity and peak expiratory flow rate were not recorded in the groups having lower abdominal operations.

Q.E. = Observer estimate. P.E. = Patient estimate. P.R.E. = Patient's retrospective estimate. V.C. = Vital capacity. P.E.F.R. = Peak expiratory flow rate.

parisons at one dose level. The doses chosen were those which appeared from the literature to be near-equipotent or to be equitoxic in terms of respiratory depression, or which were those in which the drug is at least widely used clinically. The newer preparations-fentanyl $(0.1$ and $0.2 \mathrm{mg})$, phenoperidine ( 1 and $2 \mathrm{mg}$ ); and pentazocine (20 and $40 \mathrm{mg}$ )were each studied at two dose levels, as there was little evidence in the literature at that time of their relative potencies. Morphine was also included at doses of 10 and $15 \mathrm{mg}$, as both of these are frequently used in clinical practice.

\section{Results}

The findings are presented in Table III. Pethidine $100 \mathrm{mg}$ and saline were selected as standard and placebo treatments respectively and the remaining agents classified as being superior to pethidine $100 \mathrm{mg}$, equivalent to pethidine $100 \mathrm{mg}$, or inferior to pethidine $100 \mathrm{mg}$, and superior to saline or equivalent to saline.

All drugs were better than saline (minimum value $P<0.025$ ) but only levorphanol $2 \mathrm{mg}$ proved significantly superior to pethidine $100 \mathrm{mg}(\mathrm{P}<0.05)$.
The commonly used doses of these drugs placed in rank order with respect to incidence of successful postoperative pain relief according to the criteria described above are given in Table IV. This table ignores differences of less than $5 \%$.

\section{Discussion}

The objective of this investigation was the selection of the most successful out of the many currently available analgesic drugs. The difficulty of making such a choice on the basis of existing literature has already been mentioned, arising from differences in methodology. The logical approach was the inclusion of all of the agents in question in one trial carried out under standard conditions. This imposed limits on the number of patients receiving each drug and consequently reduced the chance of demonstrating statistically significant differences between treatments. Nevertheless, it also implied that such distinctions as were found would probably be of clinical as opposed to purely statistical importance.

It must also, of course, be remembered that analgesic potency represents only one aspect of a drug's performance; the incidence and severity of side effects being at least equally 
important in determining its clinical value, and these have already been reported in respect of the drugs included in this trial (Loan et al., 1969; Morrison et al., 1969; Dundee et al., 1970).

Before discussing individual drugs it is worth considering the rank order of efficacy of the analgesics studied (Table IV) compared with a similar grading of efficacy based solely on the patient's estimation of pain relief (Table $V$ ). This distinguishes less clearly between the most effective drugs but suggests that either respiratory depression or oversedation placed pethidine and pethilorfan in a less favourable position (Table IV). We were surprised to find that the very popular pethidine showed up so poorly in the evaluation shown in Table IV compared with that in Table V. This was due to the fact that patients receiving it were so heavily sedated that they were unable to perform the tests of respiratory function. (The method of assessment in Table IV is, of course, designed to favour agents producing freedom from pain with minimum impairment of consciousness.) It is also interesting to note that while morphine $10 \mathrm{mg}$ and pethidine $100 \mathrm{mg}$ will produce about the same incidence of drowsiness in patients before operation (Dundee et al., 1965) unpublished findings have shown that when given postoperatively pethidine $100 \mathrm{mg}$ was associated with a pronounced depression of consciousness in $55 \%$ of cases as compared with $37 \%$ in the case of morphine $10 \mathrm{mg}$. This tendency for pethidine to cause cerebral depression in the postoperative period has previously been commented on by Bromage (1955) and Masson (1962).

Levorphanol, at a dose of $2 \mathrm{mg}$, clearly emerged as the most effective agent according to the criteria adopted in this trial. It has previously been shown to be a powerful analgesic (Glazebrook, 1952; Hunt and Foldes, 1953) with a lower incidence of drowsiness than morphine (Brown, 1954), and might be expected to provide the pain relief with minimal depression of consciousness sought in this trial.

Oxycodone $10 \mathrm{mg}$, pentazocine $20 \mathrm{mg}$, and the morphine $10 \mathrm{mg}$ and cyclizine $50 \mathrm{mg}$ (Cyclimorph 10) combination were the most successful of the remaining drugs though not significantly better than the standard pethidine $100 \mathrm{mg}$.

There is little published work on the analgesic effectiveness of oxycodone but it has been suggested that the pectinate has a potency similar to that of morphine (Eddy et al., 1957 Brittain, 1959), and this relationship has been to some extent confirmed in this study. In a study of side effects of various analgesics we found this to be fairly non-toxic (Dundee et al., 1970).

Pentazocine $20 \mathrm{mg}$ compared favourably with most of the established potent analgesics, confirming reports of its efficacy against postoperative pain (Keats and Telford, 1964; Conaghan et al., 1966). While early claims that this drug was totally free from addiction potential have not been fully supported the magnitude of this risk can be judged from the fact that, after some four years of widespread use in Britain, it is not subject to control under the dangerous drugs legislation.

Diamorphine $5 \mathrm{mg}$ did not in this trial display any unique properties, and the results tend to support the view of Lasagna (1964) of the essential similarity between diamorphine and morphine. It must be remembered, however, that diamorphine in solution is quite rapidly broken down to monacetylmorphine and morphine (Storey, 1944), and that where a necessarily prolonged study is carried out under blind conditions it is impossible to be certain that the agent used is in all cases pure. In clinical practice, of course, where the identity of the drug need not be concealed, the current widespread use of solutions freshly prepared from diamorphine powder should overcome this difficulty.

Studies in animals suggested that the analgesic effectiveness of fentanyl in terms of milligramme potency would be 200400 times that of morphine. The results in this trial, however, where fentanyl $0.2 \mathrm{mg}$ proved equianalgesic to morphine $10 \mathrm{mg}$, would suggest that milligramme potency of fentanyl is of the order of 50 times that of morphine. This potency ratio is in keeping with the respiratory depressant ratio found by Stephen (1967)-namely, that $0.15 \mathrm{mg}$ of fentanyl produced a similar degree of respiratory depression to that of morphine $10 \mathrm{mg}$. Finch and de Kornfeld (1967) reported comparable results from a trial in patients with acute pain-namely, that the analgesic potency of fentanyl $0.2 \mathrm{mg}$ was similar to that of morphine $10 \mathrm{mg}$. This drug serves once again to show the irrelevancy of milligramme potency in the pharmacology of an analgesic drug. The fact that by weight fentanyl is $\mathbf{5 0}$ times as potent as morphine, or 500 times as potent as pethidine, is of little value when, at acceptable levels of toxicity, it is no more effective in relief of pain and is appreciably more toxic (Dundee et al., 1970).

As in the case of fentanyl there is a wealth of data from animal experiments on which to base an estimate of comparative analgesic performance ratio for phenoperidine and morphine. In milligramme potency this ratio would appear to assess phenoperidine as being from 15 to 75 times as potent as morphine. Again, however, the present studies suggest that these ratios are not applicable to its analgesic effectiveness in man and indicate that the truer ratio lies in the region of 5:1. Search of the literature has failed to produce any other report of the analgesic effectiveness of this drug.

While classified in this paper as a single agent, papaveretum is, of course, a mixture of morphine with three opium alkaloids -codeine, narcotine, and papaverine. Papaveretum $20 \mathrm{mg}$ contains, in fact, morphine alkaloid equivalent to that contained in morphine sulphate $13.3 \mathrm{mg}$ (Loan et al., 1966). Many unconfirmed claims have been made regarding the superior analgesic potency of papaveretum as opposed to morphine alone (Gray, 1911; Schall, 1917), but the findings of this study do not support this view.

Four drugs were studied at more than one dose level-namely, morphine at 10 and $15 \mathrm{mg}$, pentazocine at 20 and $40 \mathrm{mg}$, fentanyl at 0.1 and $0.2 \mathrm{mg}$, and phenoperidine at 1 and $2 \mathrm{mg}$. It is noteworthy that in the cases of phenoperidine and fentanyl the difference in analgesic potency between a clinical dose and one considerably lower was reflected in improved performance, whereas with morphine and pentazocine an increase in dosage above the usual levels produced, if anything, a slight reduction in the desired effect. This supports the concept of a non-linear dose response curve for analgesic drugs and the importance of selecting the optimum dose of each agent.

Four analgesics were studied in combination with other drugs-namely, phenoperidine $2 \mathrm{mg}$ and fentanyl $0.2 \mathrm{mg}$ with dehydrobenzperidol $5 \mathrm{mg}$, morphine $10 \mathrm{mg}$ with cyclizine $50 \mathrm{mg}$, and pethidine $100 \mathrm{mg}$ with levallorphan $1.25 \mathrm{mg}$ (Pethilorphan 100). Only in the case of the morphine-cyclizine preparation was there any appreciable improvement in analgesic potency, though this did not reach levels of statistical significance. In the absence of any indication that cyclizine has inherent analgesic properties it is possible that reduction in side effects might have resulted in greater patient comfort. The addition of dehydrobenzperidol $5 \mathrm{mg}$ to fentanyl $0.2 \mathrm{mg}$ had minimal effect on analgesic potency. There is some difference of opinion in the literature regarding the analgesic status of this combination of drugs. Foldes et al. (1964) and Fox et al. (1967) have suggested that dehydrobenzperidol either has some analgesic effect itself or is capable of enhancing the effects of the opiate analgesics. In contrast, Morrison (1970) found that droperidol given alone increased the subject's sensitivity to experimentally-induced pain, and, when given in the combinations commonly employed in neuroleptic anaesthesia it appeared to reduce the analgesic action of phenoperidine and fentanyl. With the number of subjects in each treatment group in this trial, however, it is likely that a clinically significant difference in potency would be shown by a statistically significant difference.

The combination of levallorphan with pethidine was associated with a fall in analgesic potency of the latter, and this 
mixture has little to commend it in clinical practice (Telford and Keats, 1961; Campbell et al., 1965).

This work was supported by fellowships from the Medical Research Council and Royal Victoria Hospital, Belfast, to whom we are indebted. We also acknowledge the assistance of the staff of the hospital recovery ward for their co-operation.

\section{References}

Brittain, G. J. C. (1959). Lancet, 2, 544.

Bromage, P. R. (1955). British Medical fournal, 2, 589

Brown, A. K. (1954). British Medical fournal, 2, 967

Campbell, D., Masson, A. H. B., and Norris, W. (1965). British fournal of Anaesthesia, 37, 199.

Conaghan, J. P., Jacobsen, M., Rae, L., and Ward-McQuaid, J. N. (1966). British fournal of Anaesthesia, 38, 345.

Dundee, J. W., Clarke, R. S. J., and Loan, W. B. (1965). Lancet, 2, 1262. Dundee, J. W., Loan, W. B., and Morrison, J. D. (1970). British fournal of Anaesthesia, 42, 54.

Eddy, N. B., Halbach, H., and Braenden, O. J. (1957). Bulletin of the World Health Organization, $17,569$. Finch, J. S., and de Kornfeld, T. J. (1967). Fournal of Clinical Pharmacology
and fournal of New Drugs, 7,46 .
Foldes, E. F., Kepes, E. R., Torda, T. A. G., Bailey, R., and Wulfsohn, N.L. (1964). In Proceedings of the 3rd World Congress on Anaesthesiology (Sao Paulo), vol. 2, p. 239

Fox, J. W. C., Fox, E. J., and Crandell, D. L. (1967). Archives of Surgery, 94.102.

Glazebrook, A. J. (1952). British Medical fournal, 2: 1328.

Gray, H. M. (19i1). Lancet, 1, 779 .

Hunt, R. D., and Foldes, F. F. (1953). New England fournal of Medicine, 248, 803 .

Keates, A. S., and Telford, J. (1964). Fournal of Pharmacology and Experimental Therapeutics, $143,157$.

Lasagna, L. (1964). Pharmacological Reviews, 16, 47.

Loan, W. B., Dundee, J. W., and Clarke, R. S. J. (1966). British fournal of Anaestheisa, 38, 891.

Loan, W. B., Morrison, J. D., and Dundee, J. W. (1968). Clinical Pharmacology and Therapeutics, $9,765$.

Loan, W. B., et al. (1969). British fournal of Anaesthesia, 41, 57.

Masson, A. H. B. (1962). Current Researches in Anesthesia and Analgesia, $41,615$.

Morrison, J. D. (1970). British fournal of Anaesthesia, 42, 838.

Morrison, J. D., Loan, W. B., Dundee, J. W., McDowell, S. A., and Brown, S. S. (1969). British fournal of Anaesthesia, 41, 987.

Schall, J. H. (1971). Long Island Medical fournal, 11, 187.

Stephen, G. W. (1967). Personal communication.

Storey, G. A. (1944). Quarterly fournal of Pharmacy and Pharmacology, $17,225$.

Telford, J., and Keats, A. S. (1961). Anesthesiology, 22, 465.

\section{MEDICAL MEMORANDA}

\section{Cervical and Mediastinal Fibrosis Presenting with Thyroid Swelling}

\author{
R. A. W. MCDOWALL
}

British Medical fournal, 1971, 3, 290

A woman presenting with a thyroid swelling was found to be suffering from cervical and mediastinal fibrosis. The aetiology and association with other conditions are discussed.

\section{Case History}

Twenty years before the present admission the patient had been investigated for thyrotoxicosis, and a small hard thyroid swelling had been noted. Now 52 years old she complained of hoarseness of the voice, a feeling of pressure on the throat, and occasional dysphagia and dyspnoea. On examination she was found to have a large non-toxic nodular goitre with retrosternal extension confirmed by $X$-ray examination. Results of blood tests, including proteinbound iodine and thyroid antibody tests, were all normal, and thyroid scan showed only two small areas of functioning tissue. Indirect laryngoscopy showed a paralysed right vocal cord.

At operation on 13 March 1969 initial appearances suggested thyroid carcinoma, but it was found that the right lobe could be enucleated from a bed of dense fibrous tissue which extended into the mediastinum. Most of this and the left lobe was removed and the resultant fixed-walled cavity drained. Histological examination showed a simple goitre in which the capsular tissues were infiltrated with inflammatory cells including many plasma cells, and there were some similar scattered deposits in the gland. Lymph nodes showed reactive hyperplasia only.

One month after discharge the patient complained of increasing dyspnoea, and examination showed venous congestion of the right side of the neck, and mild ptosis of the right lid. A hard mass could be felt extending from neck to sternum. Tomograms showed a large swelling extending into the mediastinum and compressing the trachea, but the barium swallow was normal. Sedimentation rate was raised from 13 to $57 \mathrm{~mm}$, there was an increase in the

United Oxford Hospitals Group

R. A. W. MCDOWALL, F.R.C.s., Surgical Registrar gammaglobulin protein fraction, but no gastric or thyroid autoantibodies could be detected.

At bronchoscopy the right vocal cord was still paralysed and the trachea was rigid and compressed from the right side, the mucosa being congested down to the carina, beyond which it was normal. At thoracotomy the apex of the lung was found to be adherent to a hard pale mass extending from the thoracic inlet and engulfing the superior vena cava and lung surface. A line of cleavage was made between lung and mediastinum, further surgery being considered too hazardous. Histological examination showed dense fibrous tissue with prominent vessels and patchy inflammatory cell infiltration. As no thyroid tissue was present a diagnosis of mediastinal fibrosis was made.

Postoperatively the patient was started on prednisolone $30 \mathrm{mg}$ daily with some improvement in venous pressure in the neck. Over the following year she remained in reasonable health with only slight dyspnoea and hoarseness. When last seen venous pressure was only slightly raised and she was taking prednisolone $15 \mathrm{mg}$ daily.

\section{Comment}

Mediastinal fibrosis associated with and antedating retroperitoneal fibrosis has been reported (Tubbs, 1946; Calne et al., 1966) but cervical fibrosis has not been mentioned. The present patient had no clinical evidence of the retroperitoneal condition. Renal function was normal but intravenous pyelography showed minor clubbing of the calices on the right. At hysterectomy two years previously no abnormal reiroperitoneal tissues had been observed. There was also no history of methysergide therapy.

The simple goitre was probably incidental to the fibrosis, but as the microscopical appearances of mediastinal fibrosis have been compared with those of Riedel's thyroiditis and other fibrosing conditions (Barrett, 1958) and a common inflammatory aetiology has been suggested I wonder if this is a way along which Riedel's thyroiditis could have developed.

I wish to thank Mr. R. G. Reid, of the Royal Berkshire Hospital, and Mr. C. Grimshaw and Dr. A. Karlish for permission to report this case of a patient under their care.

\section{References}

Barrett, N. R. (1958). British fournal of Surgery, 46, 207.

Calne, R. Y., Loughridge, L. W., and Morgan, A. D. (1966). Lancet, $1,67$.

Tubbs, O. S. (1946). Thorax, 1, 247. 